\title{
DELETIONS OF MITOCHONDRIAL DNA IN KEARNS-SAYRE SYNDROME
}

M. Zeviani, C. T. Moraes, S. DiMauro, H. Nakase, E. Bonilla, E. A. Schon, and L. P. Rowland

Neurology 1988;38:1339-1346

We have identified large-scale deletions in muscle mitochondrial DNA (mtDNA) in seven of seven patients with Kearns-Sayre syndrome (KSS). We found no detectable deletions in the mtDNA of ten non-KSS patients with other mitochondrial myopathies or encephalomyopathies, or three normal controls. The deletions ranged in size from 2.0 to $7.0 \mathrm{~kb}$, and did not localize to any single region of the mitochondrial genome. The proportion of mutated genomes in each KSS patient ranged from $45 \%$ to $75 \%$ of total mtDNA. There was no correlation between the size or site of the deletion, biochemical abnormality of mitochondrial enzymes, or clinical severity. The data bolster arguments that KSS is a unique disorder and genetic in origin.

Free Access to this article at www.neurology.org/content/38/8/1339

Comment from Andrew G. Engel, MD, FAAN, Associate Editor: This article set the stage for the diagnosis of mitochondrial myopathies due to large-scale deletions in mitochondrial DNA. 


\title{
Neurology
}

\author{
Deletions of mitochondrial DNA in Kearns-Sayre syndrome \\ M. Zeviani, C. T. Moraes, S. DiMauro, et al. \\ Neurology 2011;77;1090 \\ DOI 10.1212/01.wnl.0000405387.42287.b2
}

This information is current as of September 12, 2011

\section{Updated Information \&}

Services

Permissions \& Licensing

Reprints including high resolution figures, can be found at:

http://n.neurology.org/content/77/11/1090.citation.full

Information about reproducing this article in parts (figures,tables) or in its entirety can be found online at:

http://www.neurology.org/about/about_the_journal\#permissions

Information about ordering reprints can be found online:

http://n.neurology.org/subscribers/advertise

Neurology ${ }^{\circledR}$ is the official journal of the American Academy of Neurology. Published continuously since 1951, it is now a weekly with 48 issues per year. Copyright Copyright $@ 2011$ by AAN Enterprises, Inc.. All rights reserved. Print ISSN: 0028-3878. Online ISSN: 1526-632X.

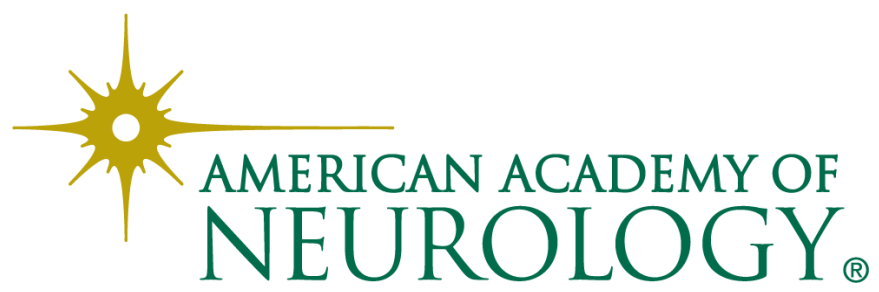

